\title{
Firm-Level Determinants Of Export Performance
}

\author{
Muhammad Suhail Nazar, The Islamia University of Bahawalpur, Pakistan
} Hassan Mujtaba Nawaz Saleem, The Islamia University of Bahawalpur, Pakistan

\begin{abstract}
Contribution of small and medium enterprises (SMEs) in global export is becoming significant but still a large number of these are unable to outperform in international market. In this study, we have identified and classified the firm-level controllable determinants of export performance. Based upon a comprehensive and systematic literature study we finally developed a synthesized model which may provide a broader understanding of the export behavior of the SMEs to enhance their export performance. Many information sources have been explored to collect the relevant literature. The determinants found from the literature are classified into firm's characteristics, management characteristics, and export marketing strategic capabilities. In this paper, we have proposed a synthesized model for the researchers who are interested to investigate the issue further (i.e. about SMEs export performance determinants).
\end{abstract}

Keywords: Export Performance, Product Capabilities, Management Characteristics, Export Marketing, Firm's Characteristics, Synthesized Model, SMEs.

\section{FIRM-LEVEL DETERMINANTS OF EXPORT PERFORMANCE}

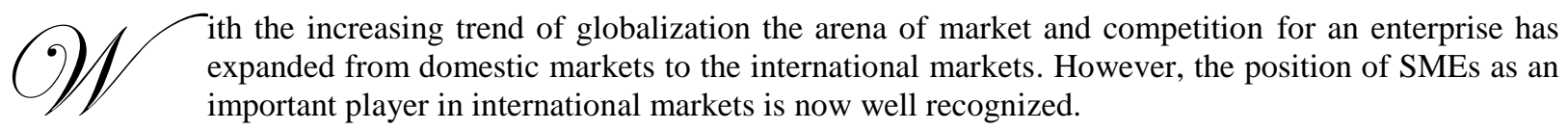

Ibeh (2004) have documented that SMEs share in the world's manufactured exports is 25-35 percent and their contribution to the GDP is 4-6 percent and 12 percent in OECD (Organization for Economic Co-operation and Development) countries and Asian economies respectively. Neither all SMEs are involved in exporting nor do all exporting SMEs perform at equal success level. Various researchers investigating about how firms perform in exporting have identified a lot of factors as determinants of export performance (Aaby and Slater (1989); Ibeh (2003); Dijk (2002); Zuo and Stan (1998)). These determinants have been classified differently; however, a major classification has been as controllable and controllable. The controllable determinants are internal firm-level and uncontrollable are external environmental determinants (Tesfom and Lutz (2006); Aaby and Slater (1989); Dijk (2002)).

In this study we focus on the factors that are classified as firm-level controllable determinants which influence the export performance of SMEs. Although various researchers have already investigated this issue and have identified different firm-level determinants, such as:

- firm structural characteristics, market orientation, market characteristics, managerial attitudes (Chetty and Hamilton (1993); Madsen (1989)),

- $\quad$ competencies, market orientation, firm characteristics and management perception (Aaby and Slater (1989));

- $\quad$ strategy factors, management attitude and perception, export marketing strategy and marketing mix variables (Zou, Stan (1998));

- behavioral control strategy, export sales organization design, export manager characteristics, export manager behavioral attributes (Katsikea and Skarmeas (2003)) and; 
- $\quad$ firm specific characteristics and product characteristics (Julian (2003).

But, the changes in environmental factors such as technological, economic, and social conditions guides to innovative research questions and alternative elucidations for how firms export performance is determined. At present, adequate literature is available on the issue, however, what is desirable is to systematically synthesize the existing literature in order to spot the similarities and synthesize these determinants to provide a comprehensive integrated model to reach at a common base for supplementary exploration. Thus, the primary objective of this paper is to recognize the firm level determinants and categorize them to develop a synthesized model.

From the literature review dozens of variables are found. However, these variables can be clustered into a condensed number of more wide-ranging variables on the bases of their conceptualized similarity. The purpose is to avoid the repetition of variables with different names and to facilitate the answer to research questions in order to develop a synthesized model (please see Figure 1):

\section{Export Performance}

Shoham (1996) has generally defined export performance as the result of a firm's actions in export markets. Although, growing body of literature has addressed the issue but still there is no evenly accepted conceptual and operational framework (Cavusgil and Zou (1994); Shoham (1998)). Sousa (2004) has identified about 50 dimensions of export performance measure which are classified as subjective and objective measures of export performance. However, Leonidou et. al. (2002), have identified that export proportion of sales or export intensity, export sales growth, export profit level, export sales volume, export, market share, and export profit contribution are mostly used measures of export performance.

\section{Management Characteristics:}

The occurrence of controllable factors suggests that export performance is under the control of the organization and its executives, so they are considered to be the responsible for both excellent and poor performance of export (Zou, Stan (1998)).

Many researchers have studied the management characteristics as determinants of export performance through different dimensions (Aaby and Slater (1989); Ibeh (2003); Suárez-Ortega et. al. (2005)). To synthesize these diverse characteristics are classified into categories namely "attitudinal characteristics" "skill based characteristics" and "behavioral characteristics"

\section{Attitudinal Characteristics}

A number of determinants are found that can be classified as the management attitudinal determinants. These include, among others, management's international orientation, management's export commitment; management's perceived export advantages and barriers of exporting (Zou and Stan (1998)).

- Management Commitment: Management's export commitment is one of the key determinants of export performance (Aaby and Slater (1989); Zou and Stan, (1998)). Cavusgil and Zou (1994) found that high management commitment allows to follow successful export marketing strategies that help to enhance export performance which is confirmed by Julian (2003)

- Management perception toward competitiveness: Management perception in the competitiveness of the export product has relation with the exporting result of the companies (Madsen (1998); Eusebio et. al. (2007)), found that Greater management confidence in the competitiveness of the export product increase the export intensity of the firm.

- Management Perception towards export advantages: How management foresee the export advantages and their contribution to export profits are the good determinants of export performance. (Axinn (1988); Aaby and Slater (1989); Zou and Stan (1998)). 
- $\quad$ Management Perception toward export barriers: Literature reviewed by Abey and Slater (1989); Zou and Stan (1998) found Management perception toward supposed export barriers such as expected risk, costs involved and intricacy of export to be the important forecaster's of export excellence.

- Management's international orientation: International vision (Aaby and Slater (1989)) and international orientation (Zou and Stan, (1998)) are considered to be regular forecaster of export performance. Most probably, an international firm can better see opportunities and stay away from threats

- Management's customer Orientation: Katsikea and Skarmeas (2003) has found that export manager's high level of customer orientation contribute to effective export performance and low level leads to less effective export performance.

\section{Skill Based Characteristics}

A number of determinates are found that can be classified as the management skill based determinants of export performance. These include managers' experience, education level, and foreign language proficiency.

- $\quad$ Export Experience: There is a positive relationship of export experience with export propensity (Ibeh (2003)) and intensity (Suárez-Ortega and Álamo-Vera, (2005)).

- $\quad$ Foreign Language Proficiency: Suárez-Ortega and Álamo-Vera, (2005) have fond managers' foreign language proficiency positively correlated with both export propensity and intensity. Similar results are found by Louter et. al. (1991)

- $\quad$ Education Level: Suárez-Ortega and Álamo-Vera, (2005) have identified a positive however weak correlation of education level with export performance.

\section{Behavioral Characteristic}

Katsikea and Skarmeas (2003) has identified that the fashion of managers' involvement in export sales planning, export sales presentation, adaptive selling and sales support etc. to differentiate low and superior export sales effectiveness.

\section{Firm's Characteristics and Competencies:}

\section{Firm Size}

Firm size is taken as controllable factor and is an important determinant of export performance (Aaby and Slater, 1989). A literary review by Zou and Stan (1998) has found its mixed affects; firm size has positive effect on export performance if measured in terms of total sales and has negative effects are found on export profits if measured by number of employees a firm have.

\section{Technology level}

Technological intensity has a mixed outcome on export performance (Zou and Stan (1998)). However, Madsen (1987); and Aaby and Slater (1989) have found that technological orientation of a firm has vague effect on the export performance.

\section{Foreign Contacts and networking}

Louter et al. (1991) found frequent customer contact to be a determinant of export performance. Babakus and Yavas (2006) have found that the foreign networking (i.e. having ties with foreign entities) has a significant positive influence on export performance. 


\section{Knowledge}

Firms' export market knowledge is a critically important competence which influence export performance (Aaby and Slater (1989)) which positively affect the export performance Hart et. al. (1994), however, Toften (2005) has found a weak correlation between the two.

\section{Export Planning}

Aaby and Slater (1989) found systematic export planning very important in export operations. Zou and Stan (1998) found export planning is a reliable determinant of export performance.

\section{Export Marketing Strategic Capabilities:}

According to Shamsuddoha and Ali (2006) it is ability of a firm to respond to marketing forces to achieve its objectives. Cavusgil and Zou (1994)) pointed out that the exporting firm's performance can be measured by its marketing strategies and her ability to apply them. Export marketing strategy is usually considered as result of firms characteristics (Aaby and Slater (1989); Cavusgil and Zou (1994)) but here we take strategic capability as an independent factor. Export marketing strategic capabilities include among others the capabilities to adapt marketing mix (e.g. Product, Price, Promotion and Placement) and marketing channel strategies such as channel type and channel relationship etc. Zou and Stan (1998).

\section{Utilization of international marketing research}

It includes the firms capability to conduct international marketing research for development. Madsen (1987) found that a firm's ability to utilize international marketing research has positive effect on export sales, growth and ultimately on export performance.. Many rehearses have confirmed this relationship (Zou and Stan (1998).

\section{Segmentation and Targeting}

It includes firm's capability to implement segmentation and concentration target strategy. A meta-analysis by Leonidou et. al. (2002) found that firm's strategies of segmenting market and concentration targeting have positive relation with export performance.

\section{Product Capabilities}

The firm's ability to offer a complete product or brand mix in export markets is positively correlated with export performance (Leonidas et. al. (2002)

- Product Strengths: Julian, (2003) has found that product strengths (e.g. product uniqueness, patents, exposure to market etc.) have positive influence on export performance of the firm. Export product uniqueness (Zou and Stan (1998)) its quality and design (Leonidou et. al. (2002) are positively correlated with firms' export performance.

- Product Adaptation: Leonidou et. al. (2002) product adaptation is correlated with superior export performance. However, Eusebio et. al. (2007) found this relationship positive.

- Warranty and Customer Services: Firms' ability to offer augmented lever of product (i.e. warranty and provisions for pre- and after-sales services etc.) are positively linked with export performance as the customer is more concerned with exporters' ability to offer necessary services (Leonidou (2002)).

\section{Pricing Capabilities}

It includes the firm's capability to adapt the prices and to offer low prices. Price adaptation and ability to offer lower prices (i.e. penetration pricing strategy) are positively correlated to the export performance (Leonidou et. al. (2002). 


\section{Distribution Capabilities}

It includes the firms capability of establishing its own/direct channels, providing support to channel members, adapting distribution channels and providing in-time delivery.

- Direct Channels: Eusebio et. al. (2007) has documented that the use of corporate distribution channels, export sales representative's office and direct buying in foreign markets are positively correlated with export performance.

- Channel Relationships: Generally defined as channel members working affiliation, motivation, support and involvement have emerged as important determinant of export performance (Cavusgil and Zou (1994); Zou and Stan (1998))

- Distribution Adaptation: Many studies researched distribution adaptation, which refers to the adjustment of the exporting firm's channel design in export markets. The strong positive linkage with export performance was found. However, Zou and Stan (1998) found a mixed relationship.

- Delivery time: Delivery time plays an important role in influencing the export performance of the which is found to have a positive relationship with export performance

\section{Promotion Capabilities}

It includes firm's capability to use advertising, sales promotion, personal selling, promotion adaptation and use of export promotion programs in their export markets.

Advertising is positively related to the export performance. Similar results are found for sales promotion and personal selling, however, promotion adaptation is strongly positively correlated to export performance (Leonidou et. al. (2002); Zou and Stan, (1998)). Francis and Collins-Dodd, (2004) and Shamsuddoha and Ali (2006), have found the positive impact of use of export promotion assistance program on export performance.

\section{CONCLUSION}

Based on systematic literature review it has become possible to suggest an export performance model which may help SMEs to enhance their export performance in export market as shown in figure 1. This model synthesis dozens of export performance determinants already documented by researchers/scholars in various publications in order to develop a classification that may provides a comprehensive base for understanding firmlevel determinants of export performance. Determinants were subjectively classified into three main categories: management characteristics; firm's characteristics; and export marketing strategic capabilities.

Management characteristics that affect the export performance of the firms are further classified into attitudinal characteristics, skill based characteristics and behavioral characteristic. Firm's characteristics and competencies such as firm size, technology level knowledge etc. and export marketing strategic capabilities such as utilization of international marketing research, segmentation and targeting, product capabilities etc. also play a central role in the export performance of the SMEs. 


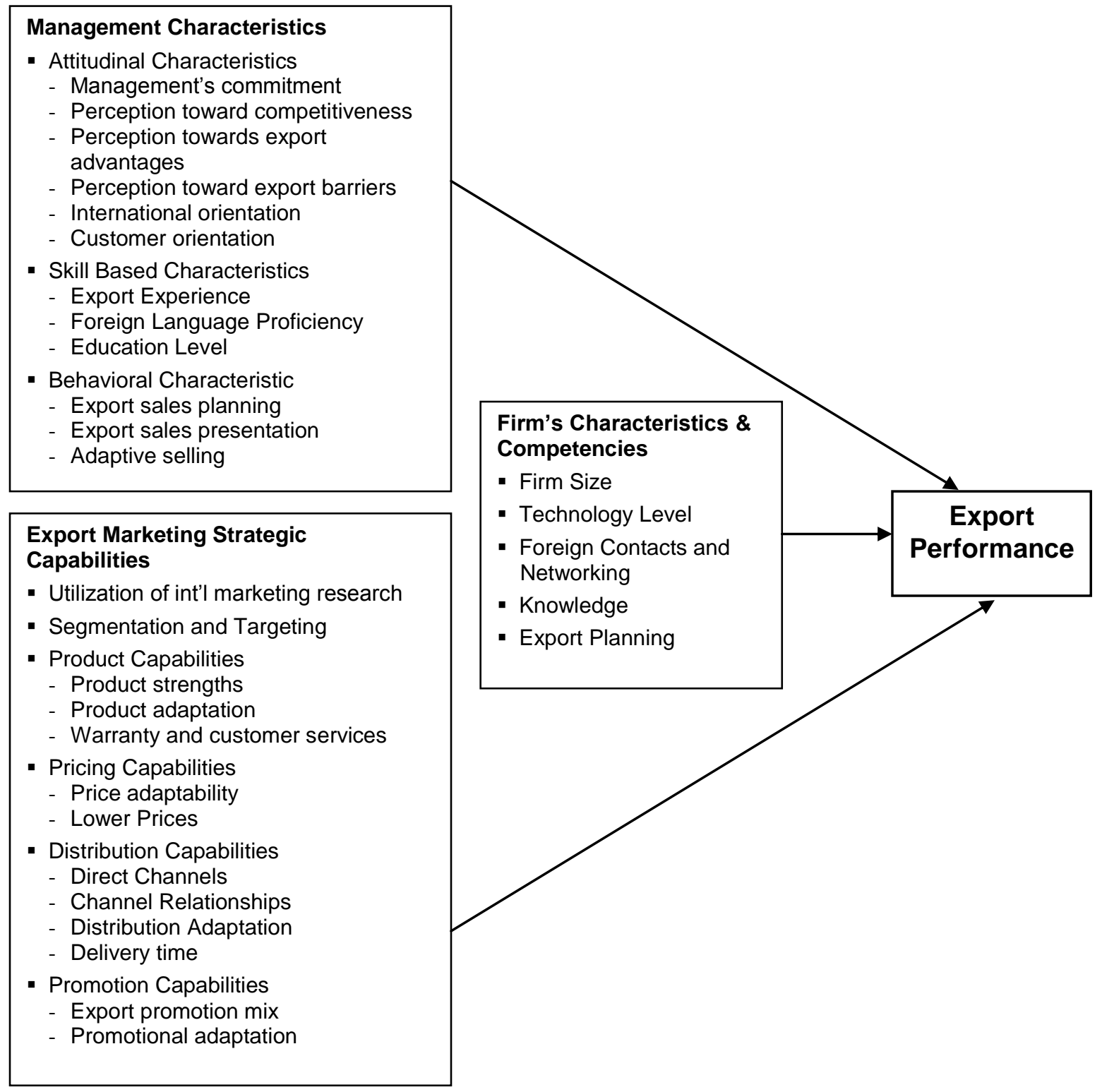

Figure 1: Conceptualization of Theoretical Framework

\section{Implications for Future Research}

The behavioral characteristics like use of export sales presentation, careful export planning etc. are also found to positively influence the SMEs' export performance In other words, managers with the suitable mix of qualities who would tend to show favorable export behavior will positively influence the export performance of SMEs. So management of SMEs should be given trainings to develop these qualities. Management must have international orientation and customer orientation to outperform in the export markets.

This synthesized model is consistent which may be used for advanced level researches on the issue, particularly, from developing countries. It also helps managers to understand the controllable factors that contribute 
in explaining the export performance of firms. It can also be used to develop a questionnaire in order to examine the relative impact of these variables on export performance for SMEs.

\section{AUTHOR INFORMATION}

Muhammad Suhail Nazar is Assistant Professor in the Department of Management Sciences, The Islamia University of Bahawalpur, Pakistan. NAZAR did his BSc. (Hons.) in Agricultural Entomology from University of Agriculture, Faisalabad in 1985. NAZAR served in Sales \& Marketing department of ICI Pakistan Ltd for five years and of DuPont Pakistan Limited for seven years. NAZAR earned his MBA in Marketing from The Islamia University of Bahawalpur in 2000 and LLB Degree from Bahauddin Zakariya University, Multan, Pakistan in 2006.

Hassan Mujtaba Nawaz Saleem is Assistant Professor at the Department of Management Sciences, the Islamia University of Bahawalpur, Pakistan. He holds multi-dimensional professional qualifications such as MBA (Finance), MAS (Applied Economics), and PGD (LA \& IW) from well-reputed institutes/universities. He possesses over ten years of experience of research/teaching. Through working with the renowned professionals/ scholars on various important short-term/long-term assignments of national/ international importance, he has developed strong ability to manage diverse set of assignments, excellent verbal and written communication skills, and work under pressure to produce good-quality output in response to the tight deadlines.

\section{REFERENCES}

1. Aaby, N.E.; and Slater, S.F. (1989), "Management influences on export performance: a review of the empirical literature 1978-88", International Marketing Review, Vol. 6 No.4, pp.7-26.

2. Axinn, C.N. (1988), "Export performance: do managerial perceptions make a difference?", International Marketing Review, Summer., .

3. Babakus, E.; and Yavas, U. (2006), "Perceived uncertainty, networking and export performance", European Business Review, Volume 18 Number 1 pp. 4-13

4. Cavusgil, S.T.; and Zou, S. (1994), "Marketing strategy-performance relationship: an investigation of the empirical link in export market ventures", Journal of Marketing, Vol. 58 pp.1-21.

5. Chetty, S.K.; and Hamilton, R.T. (1993), "Firm-level determinants of export performance: a metaanalysis", International Marketing Review, Vol. 10 No.3, pp.26-34.

6. Dijk, M.V. (2002), "The determinants of export marketing performance in developing countries: The case of Indonesian Manufacturing" Eindhoven Center of Innovation Studies, The Netherlands, Working Paper 02.01

7. $\quad$ Eusebio, R.; and Andreu, J.L.; and Belbeze, M.P.L. (2007), "Management perception and marketing strategy in export performance", Journal of Fashion Marketing and Management, Volume 11 Number 1 pp. 24-40

8. Francis, J.; Collins-Dodd, C. (2004), "Impact of export promotion programs on firm competencies, strategies and performance", International Marketing Review, Volume 21 Number 4/5, pp. 474-495

9. Ibeh, K.I.N (2003), "On the internal drivers of export performance among Nigerian firms: empirical findings and implications", Management Decision, Volume 41 Number 3 pp. 217-225

10. Ibeh, K.I.N. (2004) "Furthering export participation in less performing developing countries: The effects of entrepreneurial orientation and managerial capacity factors", International Journal of Social Economics, Volume 31 Number $1 / 2$ pp. $94-110$

11. Julian, C.C. (2003), "Export Marketing Performance: A Study of Thailand Firms", Journal of Small Business Management, 41(2), pp. 213-221

12. Katsikea, E.S.; and Skarmeas, D.A. (2003), "Organisational and managerial drivers of effective export sales organizations", European Journal of Marketing, Volume 37 Number 11/12 pp. 1723-1745

13. Katsikeas, C.S.; and Morgan, R.E. (1994), "Differences in Perceptions of Exporting Problems Based on Firm Size and Export Market Experience", European Journal of Marketing, Volume 28 Number 5 pp. 1735

14. Leonidou, L.C.; and Katsikeas, C.S.; and Samieec, S. (2002), "Marketing strategy determinants of export performance: a meta-analysis" Journal of Business Research 55 51- 67 
15. Louter, et al, Oouwerkirk, C., Bakker, B.A. (1991), "An inquiry into successful exporting", European Journal of Marketing, Vol. 25 No.6.

16. Madsen, T. (1998), "Management judgement of export performance", Journal of International Marketing, Vol. 6 No.3, pp.82-93.

17. Madsen, T.K. (1987), "Empirical export performance studies: a review of conceptualizations and findings", in Cavusgil, S.T., Axinn, C. (Eds),Advances in International Marketing, JAI Press, Greenwich, CT, Vol. 2 pp.177-98.

18. Miles, R.E., Snow, C.S. (1978), “Organizational Strategy, Structure, and Process”, Prentice-Hall, New York, NY

19. Shamsuddoha, A.K.; and Ali, M. Y. "Mediated effects of export promotion programs on firm export performance" Asia Pacific Journal of Marketing and Logistics, Volume 18 Number 22006 pp. 93-110

20. Shoham, A. (1996), "Marketing-mix standardization: determinants of export performance", Journal of Global Marketing, Vol. 10 No.2, pp.3-73.

21. Shoham, A.; Evangelista, F.; Albaum, G. (2002), "Strategic firm type and export performance", International Marketing Review, Volume 19 Number 3 pp. 236-258

22. Suárez-Ortega, S.M.; and Álamo-Vera, F.R. (2005), "SMES' internationalization: firms and managerial factors", International Journal of Entrepreneurial Behaviour \& Research, Volume 11 Number 4, pp. 258279

23. Tesfom, G.; and Lutz, E. (2006), "A classification of export marketing problems of small and medium sized manufacturing firms in developing countries", International Journal of Emerging Markets, Volume 1 Number 3, pp. 262

24. Thirkell, P.C. (1998), "Export performance: success determinants for New Zealand manufacturing exporters" European Journal of Marketing, Volume 32 Number 9/10 pp. 813-829

25. Toften, K. ( 2005), "The influence of export information use on export knowledge and performance", Marketing Intelligence \& Planning, Vol. 23 No. 2, , pp. 200-219

26. Toften, K.; Olsen, S.O. (2003), "Export market information use, organizational knowledge, and firm performance, International Marketing Review, Volume 20 Number 1 pp. 95-110

27. Valos, M.; and Baker, M. (1996), "Developing an Australian model of export marketing performance determinants", Marketing Intelligence \& Planning, Volume 14 Number 3 pp. 11-20

28. Wood, V.R.; and Robertson, K.R. (1997), "Strategic orientation and export success: an empirical study", International Marketing Review, Volume 14 Number 6 pp. 424-444

29. Zou, S.; and Stan, S. (1998) "The determinants of export performance: a review of the empirical literature between 1987 and 1997”, International Marketing Review, Volume 15 Number 5 pp. 333-356 